NASA/TM-2004-212982

\title{
Printed Multi-Turn Loop Antenna for RF Bio-Telemetry
}

Rainee N. Simons

Glenn Research Center, Cleveland, Ohio

David G. Hall

ZIN Technologies, Inc., Cleveland, Ohio

Félix A. Miranda

Glenn Research Center, Cleveland, Ohio 
Since its founding, NASA has been dedicated to the advancement of aeronautics and space science. The NASA Scientific and Technical Information (STI) Program Office plays a key part in helping NASA maintain this important role.

The NASA STI Program Office is operated by Langley Research Center, the Lead Center for NASA's scientific and technical information. The NASA STI Program Office provides access to the NASA STI Database, the largest collection of aeronautical and space science STI in the world. The Program Office is also NASA's institutional mechanism for disseminating the results of its research and development activities. These results are published by NASA in the NASA STI Report Series, which includes the following report types:

- $\quad$ TECHNICAL PUBLICATION. Reports of completed research or a major significant phase of research that present the results of NASA programs and include extensive data or theoretical analysis. Includes compilations of significant scientific and technical data and information deemed to be of continuing reference value. NASA's counterpart of peerreviewed formal professional papers but has less stringent limitations on manuscript length and extent of graphic presentations.

- TECHNICAL MEMORANDUM. Scientific and technical findings that are preliminary or of specialized interest, e.g., quick release reports, working papers, and bibliographies that contain minimal annotation. Does not contain extensive analysis.

- CONTRACTOR REPORT. Scientific and technical findings by NASA-sponsored contractors and grantees.
- CONFERENCE PUBLICATION. Collected papers from scientific and technical conferences, symposia, seminars, or other meetings sponsored or cosponsored by NASA.

- SPECIAL PUBLICATION. Scientific, technical, or historical information from NASA programs, projects, and missions, often concerned with subjects having substantial public interest.

- TECHNICAL TRANSLATION. Englishlanguage translations of foreign scientific and technical material pertinent to NASA's mission.

Specialized services that complement the STI Program Office's diverse offerings include creating custom thesauri, building customized databases, organizing and publishing research results ... even providing videos.

For more information about the NASA STI Program Office, see the following:

- Access the NASA STI Program Home Page at http://www.sti.nasa.gov

- E-mail your question via the Internet to help@sti.nasa.gov

- Fax your question to the NASA Access Help Desk at 301-621-0134

- Telephone the NASA Access Help Desk at 301-621-0390

- Write to:

NASA Access Help Desk

NASA Center for AeroSpace Information 7121 Standard Drive

Hanover, MD 21076 
NASA/TM-2004-212982

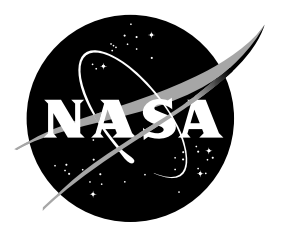

\section{Printed Multi-Turn Loop Antenna for RF Bio-Telemetry}

Rainee N. Simons

Glenn Research Center, Cleveland, Ohio

David G. Hall

ZIN Technologies, Inc., Cleveland, Ohio

Félix A. Miranda

Glenn Research Center, Cleveland, Ohio

Prepared for the

2004 Antennas and Propagation Society International Symposium and URSI National Radio Science Meeting sponsored by the Institute of Electrical and Electronics Engineers Monterey, California, June 20-26, 2004

National Aeronautics and

Space Administration

Glenn Research Center 


\section{Acknowledgments}

The NASA Glenn Research Center's Technology Transfer and Partnership Office supported this work under the research project entitled "RF Telemetry for Bio-MEMS Sensors and Actuators".

This report contains preliminary

findings, subject to revision as analysis proceeds.

Available from

NASA Center for Aerospace Information 7121 Standard Drive

Hanover, MD 21076
National Technical Information Service 5285 Port Royal Road Springfield, VA 22100 


\title{
Printed Multi-Turn Loop Antenna for RF Bio-Telemetry
}

\author{
Rainee N. Simons, ${ }^{1}$ David G. Hall, ${ }^{2}$ and Félix A. Miranda ${ }^{1}$ \\ ${ }^{1}$ NASA Glenn Research Center, Cleveland, Ohio 44135 \\ ${ }^{2}$ ZIN Technologies, Inc., Brook Park, Ohio 44142
}

\begin{abstract}
In this paper, a novel printed multi-turn loop antenna for contact-less powering and RF telemetry from implantable bio-MEMS sensors at a design frequency of $300 \mathrm{MHz}$ is demonstrated. In addition, computed values of input reactance, radiation resistance, skin effect resistance, and radiation efficiency for the printed multi-turn loop antenna are presented. The computed input reactance is compared with the measured values and shown to be in fair agreement. The computed radiation efficiency at the design frequency is about 24 percent.
\end{abstract}

\section{INTRODUCTION}

The biological and physical sciences program at NASA seeks to develop telemetry based implantable sensing systems to monitor the physiological parameters of humans during space flights [1]. This focus is rather unique when compared to efforts by other investigators, which have been mainly in the area of RF/microwave applications in medical treatment and biological effects [2].

In this paper, we present the development of a printed multi-turn loop antenna for contact-less powering and RF telemetry to acquire data from implantable bio-microelectromechanical systems (bio-MEMS) based capacitive pressure sensors. This effort is part of a U.S. patent that has been recently granted [3]. Several researchers in the past [4-6] have demonstrated RF antennas for telemetry reception from implantable sensors, and table I summarizes the type and dimensions of these antennas. However, the unique aspects of our approach are as follows: first, we make use of a multi-turn loop antenna printed on a dielectric substrate with a central annular region. The central annular region facilitates housing of signal processing circuits and thus lowers the height profile of the packaged hand-held unit. Second, the diameter of our loop antenna is significantly smaller which makes the hand-held unit very compact.

\section{RF TELEMETRY SYSTEM}

The contact-less powering and telemetry concept, is illustrated in figure 1(a). To obtain a pressure reading, a pulse emitted by the external hand-held unit initially interrogates the implanted sensor. The pulse induces a voltage in the implanted sensor inductor thus implementing contact-less powering. The waveform of this induced voltage is a decaying sine wave. Since the inductance is fixed, the frequency of the decaying sine wave is mainly determined by the capacitance of the pressure sensor. The energy radiated by the inductor during these oscillations is picked up as a telemetry signal by the receiving antenna in the hand-held unit. The notional wireless RF telemetry system [3] is illustrated in figure $1(\mathrm{~b})$.

Table I: The diameter and the type of antenna used in RF biotelemetry systems

\begin{tabular}{|l|c|c|}
\hline \multicolumn{1}{|c|}{ Type of antenna } & Antenna diameter, $\mathrm{mm}$ & Reference \\
\hline Planar spiral & 80 & Von Arx and Najafi [4] \\
\hline Disk coils & 90 & $\begin{array}{c}\text { Hamici, Itti, and } \\
\text { Champier [5] }\end{array}$ \\
\hline Solenoid coils & 100 to 150 & Troyk and Edgington [6] \\
\hline Printed multi-turn loop & 51 & This paper \\
\hline
\end{tabular}




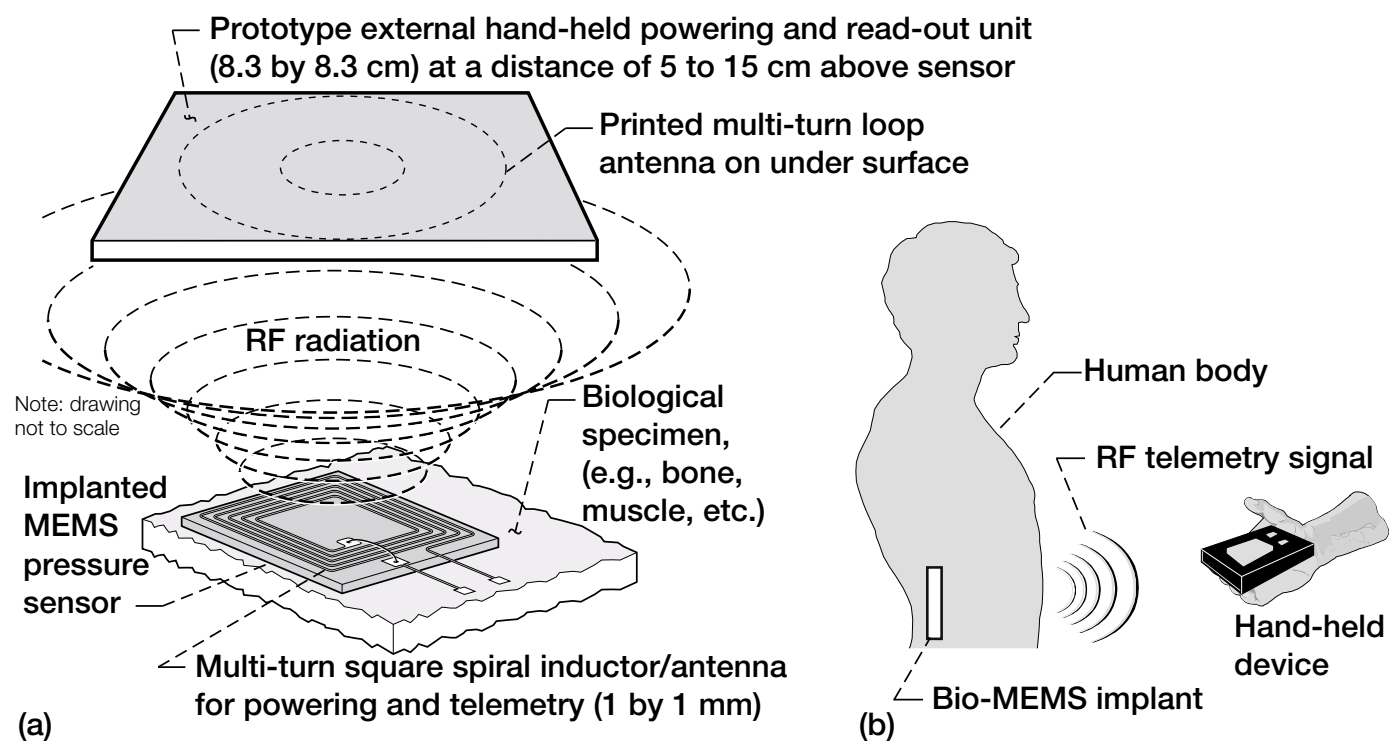

Figure 1.-Contact-less powering and telemetry. (a) Concept. (b) Application in biosensors.

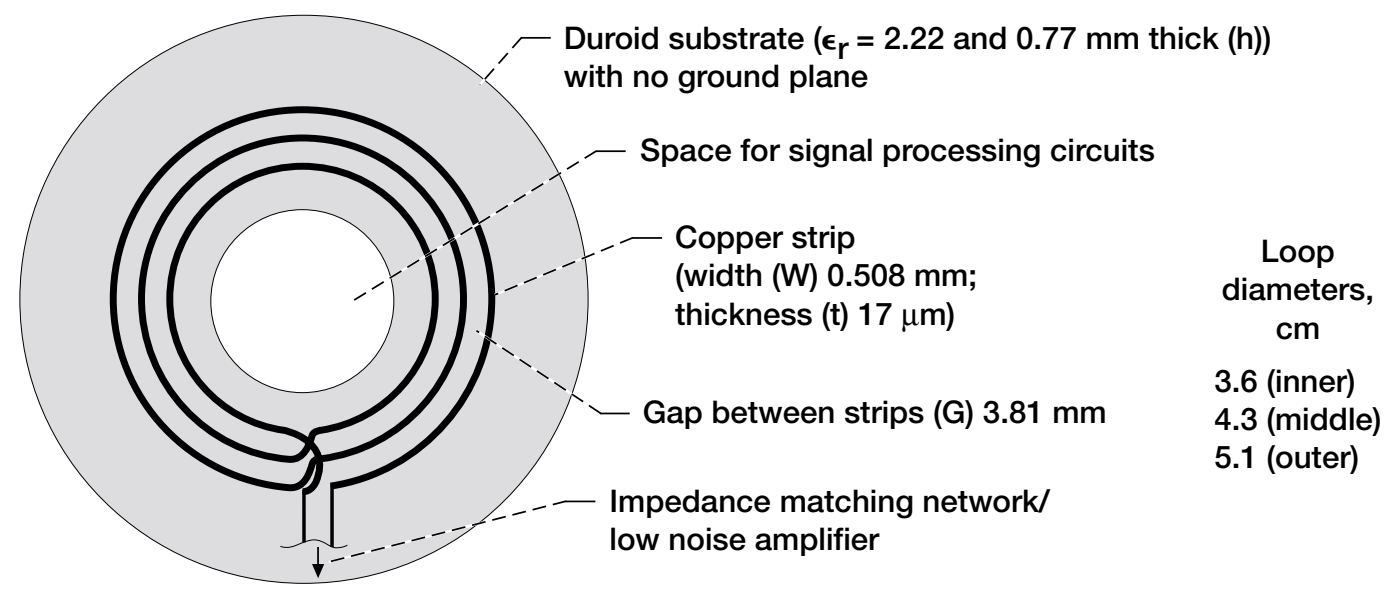

Figure 2.-Printed multi-turn loop antenna on a dielectric ring.

\section{Multi-TuRn LoOP AnTenNa ON A Dielectric RING}

\section{A. Input Reactance, Radiation Resistance, and Skin Effect Resistance}

The multi-turn loop antenna is illustrated in figure 2. The presence of a dielectric substrate of relative dielectric constant $\varepsilon_{\mathrm{r}}$ is taken into consideration in the computer model by assuming that the loop is embedded in a medium of effective dielectric constant equal to $\left(\varepsilon_{\mathrm{r}}+1\right) / 2$, [7]. In addition, the loop strip conductor of width $W$ and thickness $t$ is replaced by an equivalent wire of diameter $d=0.25 \mathrm{~W}$ [8]. Under these assumptions, the multi-turn loop with total perimeter $P$ is modeled as an equivalent lossless shorted transmission line of length $l=P / 2$ [9]. The input reactance of the loop is then equal to the transmission line input reactance. The skin effect resistance and the radiation resistance of the loop are determined using equations in [7] and [10], respectively. 


\section{COMPUTED/MEASURED RESULTS AND DISCUSSIONS}

The computed and measured reactive part of the input impedance $\left(Z_{\text {in }}\right)$ is shown in figures 3(a) and 3 (b), respectively. To measure the $Z_{\text {in }}$ of the antenna in figure 2 , a short length of a coax is soldered to the circuit and the data acquired using a microwave network analyzer (Model HP 8510C). The computed and measured results are in fair agreement. The discrepancy is because of the phase introduced by the short length of coax that is needed for interface with the test instruments, which is not trivial to calibrate out. The computed skin effect and the radiation resistances are presented in figures 4 and 5, respectively. From these results the radiation efficiency is calculated and shown in figure 6. The radiation efficiency at the design frequency of $300 \mathrm{MHz}$ is about 24 percent.

\section{CONCLUSIONS}

The paper demonstrates a novel printed multi-turn loop antenna for contact-less powering and RF telemetry from implantable bio-MEMS sensors at $300 \mathrm{MHz}$. In addition, computed values of input reactance, radiation resistance, skin effect resistance, and radiation efficiency for the loop antenna are presented. The computed input reactance is compared with the measured values and shown to be in fair agreement. The computed radiation efficiency of the loop antenna at $300 \mathrm{MHz}$ is about 24 percent.

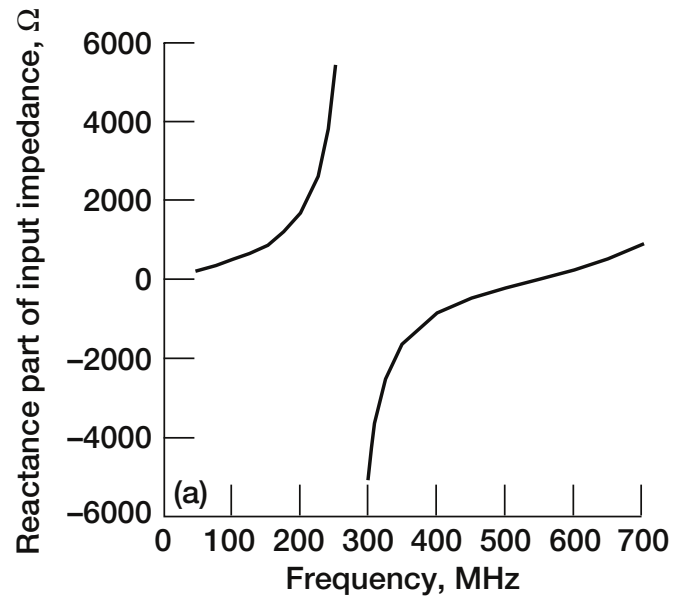

Figure 3.-Input reactance. (a)

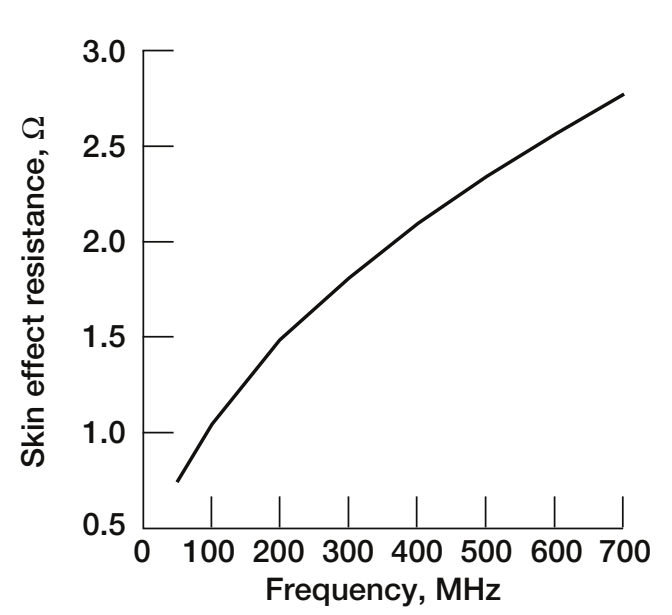

Figure 4.-Computed skin effect resistance.

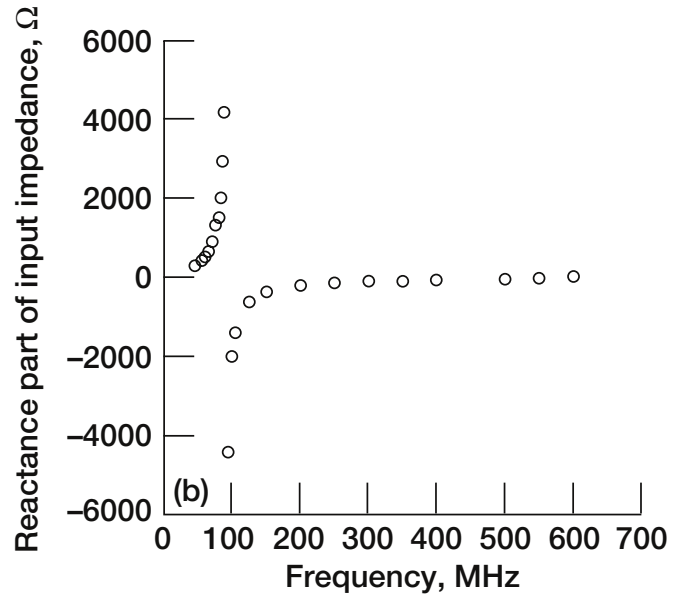

(a) Computed. (b) Measured.

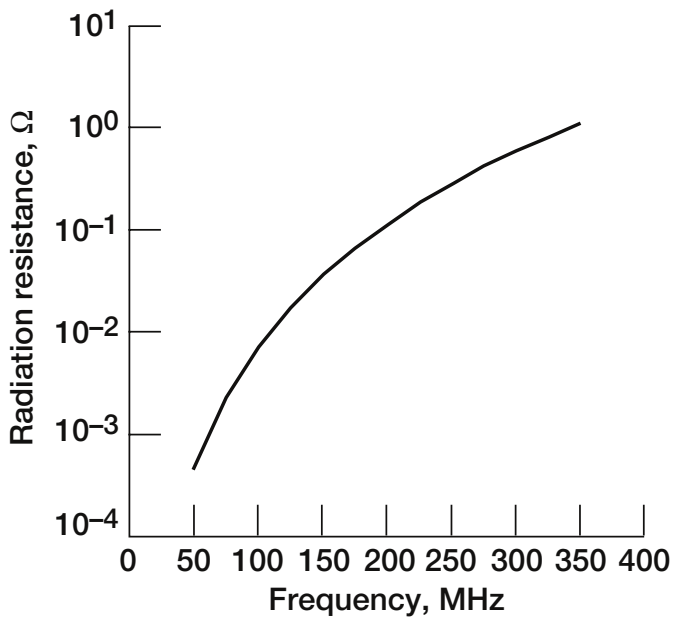

Figure 5.-Computed radiation resistance. 


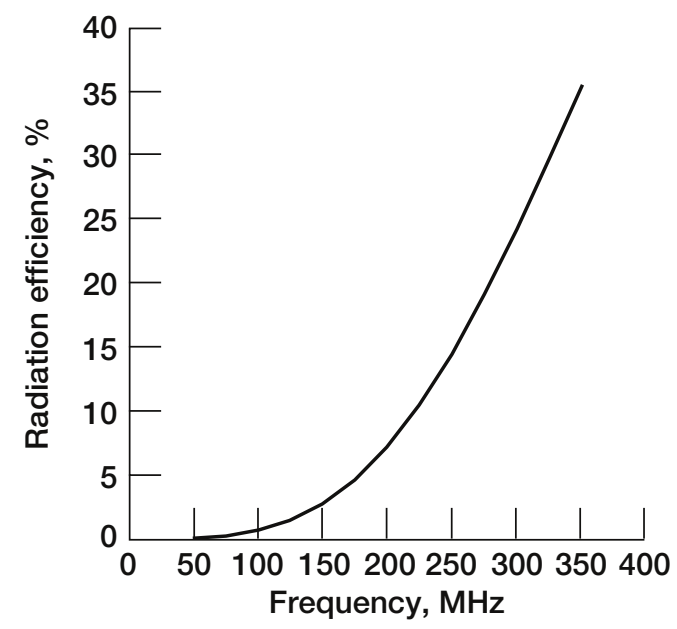

Figure 6.-Computed radiation efficiency.

\section{REFERENCES}

[1] J.W. Hines, "Medical and Surgical Applications of Space Biosensor Technology," Acta Astronautica, Vol. 38, Nos. 4-8, pp. 261-267, Feb.-April 1996.

[2] Mini-Special Issue on RF/Microwave Applications in Medicine (Part I) and Special Issue on Medical Application and Biological Effects of RF/Microwaves (Part II), IEEE Trans. Microwave Theory Tech., Vol. 48, No. 11, Nov. 2000.

[3] R.N. Simons and F.A. Miranda, Radio Frequency Telemetry System for Sensors and Actuators, U.S. Patent No. 6667725, Dec. 23, 2003.

[4] J.A. Von Arx and K. Najafi, "On-Chip Coils with Integrated Cores for Remote Inductive Powering of Integrated Microsystems," 1997 Inter. Conf. Solid-State Sensors and Actuators, TRANSDUCERS'97, pp. 999-1002, Chicago, IL, June 16-19, 1997.

[5] Z. Hamici, R. Itti, and J. Champier, "A High-Efficiency Biotelemetry System for Implanted Electronic Device," IEEE Engineering in Medicine and Biology Society 17th Annual Conference, Vol. 2, pp. 1649-1650, Montreal, Quebec, Canada, Sept. 20-23, 1995.

[6] P.R. Troyk and M. Edgington, "Inductive Links and Drivers for Remotely-Powered Telemetry Systems," IEEE Antennas and Propagation Society Inter. Symp. Dig., Vol. 1, pp. 60-62, Salt Lake City, UT, July 16-21, 2000.

[7] K. Chang, I. Bahl, and V. Nair, RF and Microwave Circuit and Component Design for Wireless Systems, New York, NY: John Wiley and Sons, 2002 (see Eq. (5.76) on p. 138 and Eq. (5.98b) on p. 151).

[8] C.A. Balanis, Antenna Theory Analysis and Design, 2nd Edition, New York, NY: John Wiley and Sons, 1997, p. 456.

[9] K.H. Awadalla and A.E.M.A. Sharshar, "A Simple Method to determine the Impedance of a Loop Antenna," IEEE Trans. Antennas and Propagation, Vol. AP-32, No. 11, pp. 12481251, Nov. 1984.

[10] G.S. Smith, "Radiation Efficiency of Electrically Small Multiturn Loop Antennas," IEEE Trans. Antennas and Propagation, Vol. AP-20, No. 5, pp. 656-657, Sept. 1972 (see Eq. (6)). 


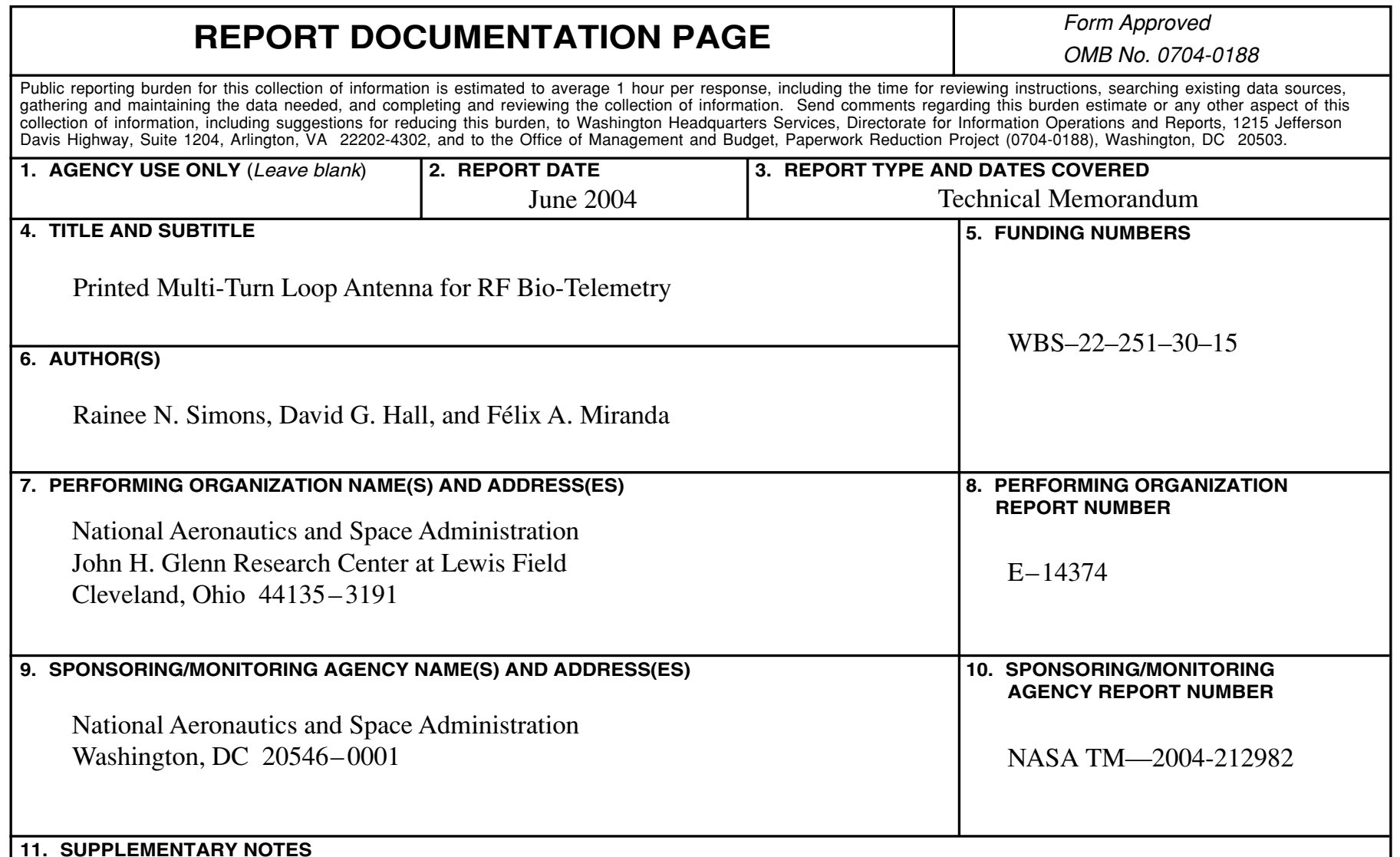

\section{SUPPLEMENTARY NOTES}

Prepared for the 2004 Antennas and Propagation Society International Symposium and URSI National Radio Science Meeting sponsored by the Institute of Electrical and Electronics Engineers, Monterey, California, June 20-26, 2004. Rainee N. Simons and Félix A. Miranda, NASA Glenn Research Center; and David G. Hall, ZIN Technologies, Inc., Cleveland, Ohio 44142. Responsible person, Rainee N. Simons, organization code 5620, 216-433-3462.

\begin{tabular}{ll|l}
\hline 12a. & DISTRIBUTION/AVAILABILITY STATEMENT & \\
Unclassified - Unlimited & Distribution: DISTRIBUTION CODE \\
Subject Category: 33 & \\
$\begin{array}{l}\text { Available electronically at http://gltrs.grc.nasa.gov } \\
\text { This publication is available from the NASA Center for AeroSpace Information, 301-621-0390. }\end{array}$ &
\end{tabular}

\section{ABSTRACT (Maximum 200 words)}

In this paper, a novel printed multi-turn loop antenna for contact-less powering and RF telemetry from implantable bioMEMS sensors at a design frequency of $300 \mathrm{MHz}$ is demonstrated. In addition, computed values of input reactance, radiation resistance, skin effect resistance, and radiation efficiency for the printed multi-turn loop antenna are presented. The computed input reactance is compared with the measured values and shown to be in fair agreement. The computed radiation efficiency at the design frequency is about 24 percent.

\begin{tabular}{|c|c|c|}
\hline \multicolumn{3}{|c|}{$\begin{array}{l}\text { 14. SUBJECT TERMS } \\
\text { Spiral inductors; Bio-MEMS; Bio-sensor system }\end{array}$} \\
\hline $\begin{array}{l}\text { 17. SECURITY CLASSIFICATION } \\
\text { OF REPORT } \\
\text { Unclassified }\end{array}$ & $\begin{array}{l}\text { 18. SECURITY CLASSIFICATION } \\
\text { OF THIS PAGE } \\
\text { Unclassified }\end{array}$ & $\begin{array}{l}\text { 19. SECURITY CLASSIFICATION } \\
\text { OF ABSTRACT } \\
\text { Unclassified }\end{array}$ \\
\hline
\end{tabular}



